\title{
Erratum to: Enantioconvergent Biohydrolysis of Racemic Styrene Oxide to R-phenyl-1, 2-ethanediol by a Newly Isolated Filamentous Fungus Aspergillus tubingensis TF1
}

\author{
Aparajita Duarah • Amrit Goswami • Tarun C. Bora • \\ Madhumita Talukdar • Binod K. Gogoi
}

Published online: 28 July 2013

(C) Springer Science+Business Media New York 2013

\section{Erratum to: Appl Biochem Biotechnol (2013) DOI 10.1007/s12010-013-0324-x}

The original version of this article unfortunately contained errors. The details are as follows:

1. Below is the correct version of Scheme 1 .<smiles>[R2]C(O)C(O)[R]C#CCCCCC</smiles>
1. $\mathrm{R}_{1}=\mathrm{C}_{6} \mathrm{H}_{5}, \mathrm{R}_{2}=\mathrm{H}, \quad$ 2. $\quad \mathrm{R}_{1}=4 . \mathrm{Cl} . \mathrm{C}_{6} \mathrm{H}_{4}, \mathrm{R}_{2}=\mathrm{H} \quad$ 3. $\mathrm{R}_{1}=3 . \mathrm{Cl} . \mathrm{C}_{6} \mathrm{H}_{4}, \mathrm{R}_{2}=\mathrm{H}$
4. $\mathrm{R}_{1}=\mathrm{R}_{2}=-\left(\mathrm{CH}_{2}\right)_{4}-$
5. $\mathrm{R}_{1}=\mathrm{CH}_{2} \mathrm{Cl}, \mathrm{R}_{2}=\mathrm{H}$

2. In line no. 4 of the "Conclusion" section where "more than $99 \%$ yield' has to be replaced with 'more than $99 \%$ conversion'.

The online version of the original article can be found at http://dx.doi.org/10.1007/s12010-013-0324-x.

A. Duarah · A. Goswami $(\bowtie) \cdot$ T. C. Bora $(\bowtie) \cdot$ M. Talukdar $\cdot$ B. K. Gogoi

CSIR-North East Institute of Science \& Technology, Jorhat 785006 Assam, India

e-mail: goswamia@rrljorhat.res.in

e-mail: tcbora@rrljorhat.res.in 